\title{
Seismic stratigraphy of the north-western Sea of Marmara shelf along the North Anatolian Fault system
}

\author{
Denizhan Vardar*,1, Hakan Alp ${ }^{2}$, Sinan Demirel ${ }^{1}$, Hande Aykurt Vardar ${ }^{2}$, Bedri Alpar ${ }^{3}$ \\ (1) Institute of Marine Sciences and Management, Istanbul University, Istanbul, Turkey \\ (2) Engineering Faculty, Geophysical Engineering Department, Istanbul University-Cerrahpasa, Istanbul, Turkey \\ (3) Salacak Mahallesi, Neyzenbası Halil Can Sokak, 88/10, Uskudar, Istanbul, Turkey
}

Article history: received October 6, 2020; accepted March 5, 2021

\begin{abstract}
The Ganos Fault, a part of the Northern strand of the North Anatolian Fault system, is an activestrike slip fault and divides the narrow NW shelf of the Sea of Marmara into two parts near the town of Gaziköy. This paper presents recently collected shallow high-resolution seismic data to discriminate the sedimentary successions, each characterized by distinctive stratigraphic patterns on both sides of the Ganos Fault. Two main units, namely U1 and U2, and three para-sequences (U1a, U1b and U1c) were identified, depending on their internal reflection patterns, accommodation depths as well as the presence of conformity and the unconformity surfaces. The thickness of Unit U1 reaches its maximum at the northern side of the Ganos Fault; it is much thinner to the south. The para-sequences of U1b and U1c have "progradation" and "aggradation to progradation" depositional characters, respectively. This probably implies fluvial deposition controlled by sealevel fluctuations. Unit U1b can only be observed at the northern side of the Ganos Fault, while Unit U1c at the southern side. Units U1a and U1b were deposited during the transgressive system tract, while Unit U1c was deposited during a sea-level fall and/or a lowstand phase marked by an erosional surface. The marine terraces in the study area are shallower than those along the northern shelf of the Sea of Marmara, possibly due to successive tectonic displacements along the Ganos Fault, which also controls the distribution and thickness of the parasequences identified in this study.
\end{abstract}

Keywords: Seismic Stratigraphy; Sea of Marmara; North Anatolian Fault system; Ganos Fault; Wave-cut Terraces.

\section{Introduction}

Fluctuations in global sea level and associated changes in sediment supplies are the primary effects that control the depositional conditions between shelves to continental margins through transgressive-regressive cycles. Highresolution seismic exploration is one of the most effective methods associated with sequence-stratigraphic concepts; it provides the best clues about the spatial and temporal record of stratal development and the surrounding environmental processes that occurred during their formation [Van Wagoner et al., 1986]. Therefore, 


\section{Denizhan Vardar et al.}

shelf-edge depositions, especially related with late Pleistocene and Holocene units, could be clearly identified and analyzed accordingly to eustatic sea-level fluctuations using high-resolution seismic data. When sediment cores and associated sequence stratigraphic analysis correlate with high-resolution seismic data [Vail 1987; Posamentier and Vail 1988; Posamentier et al., 1992], interpretation to wider areas is more accurate.

Water transfer from the Sea of Marmara to the adjacent seas (Black Sea and Aegean Sea), i.e. its paleooceanographic conditions in the late Quaternary, are controlled mainly by the morphology of the connecting straits (İstanbul and Çanakkale) in response to global sea level changes (Figure 1a). Water exchange between the Sea of Marmara and the Aegean, for example, has been cut off by a sill [Aksu et al., 1999; Çağatay et al., 2009]. Thus, during the Last Glacial Maximum (LGM), for example, the Sea of Marmara turned into a lacustrine, and its shelves were sub-aerially exposed. It was a fresh/brackish water lake between early MIS4 to MIS1, and an important regression occurred during MIS 2 [Çağatay et al., 2015]. Connection was re-established with a transition to a warming period [Çağatay et al., 2009] between 14.7 cal kyr BP [Vidal et al., 2010] $12.55 \pm 0.35$ cal kyr BP [Çağatay et al., 2015].

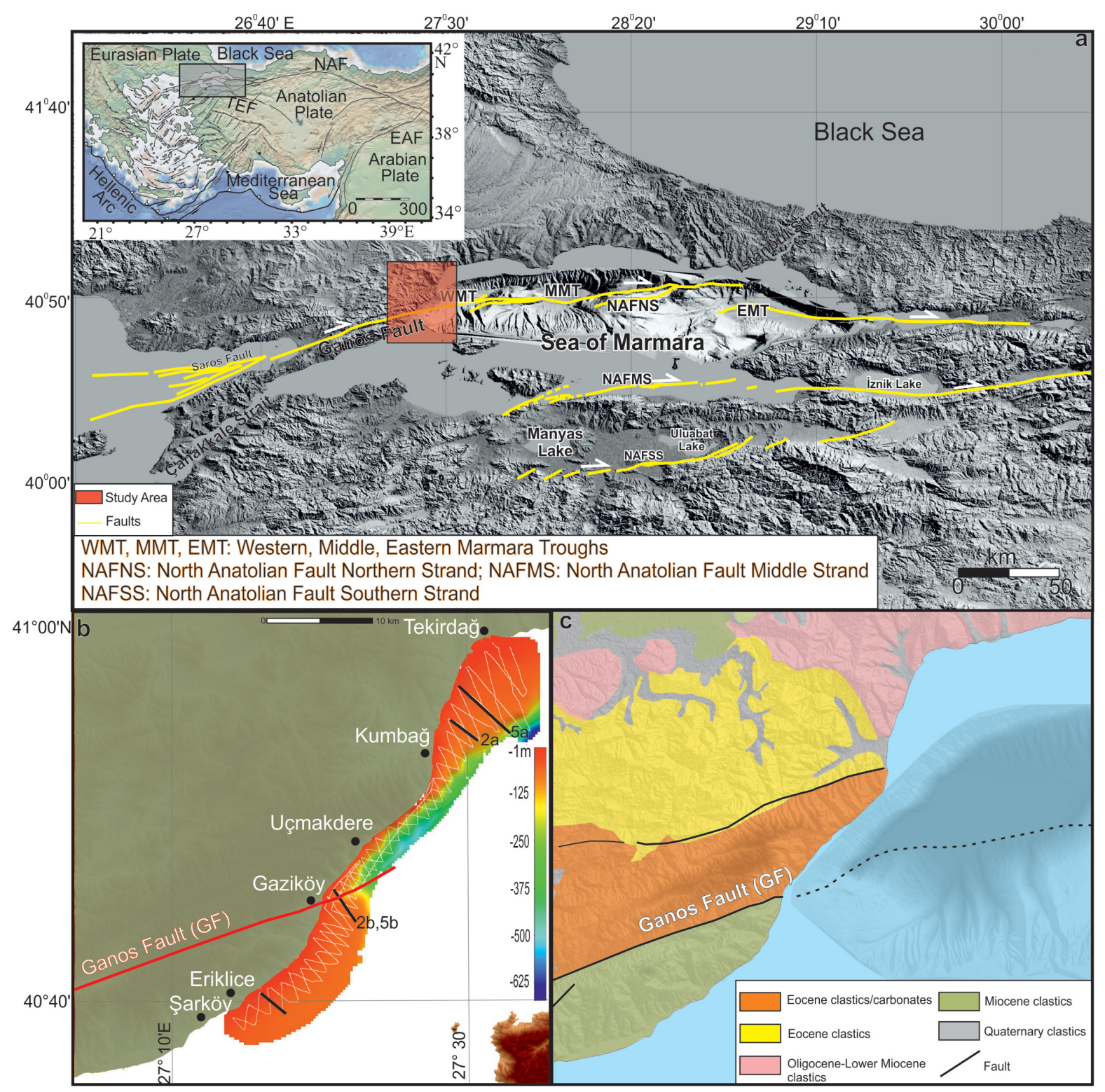

Figure 1. a) Study area and tectonic map of the Sea of Marmara, b) Bathymetric map of the study area obtained from an analysis of seismic data; the location is indicated by yellow thin lines, together with the seismic profiles of this work (thick black lines), c) geological map of the study area. 
This hydrologic switch took 1-2 kyr to be completed, and was characterized by euryhaline Mediterranean organisms called "bioherms" observed in high resolution seismic profiles [Çağatay et al., 2000, 2003, 2009; McHugh et al., 2008; Vidal et al., 2010; Eriş et al., 2011; Vardar et al., 2014; Vardar and Vardar, 2014; Köprülü et al., 2016; Aksu et al., 2016; Vardar et al., 2018].

The sedimentary succession deposited along the northern shelf of the Sea of Marmara consists of a young and relatively thin layer, overlying an acoustic basement not penetrated by high-frequency seismic sources [Aksu et al., 1999; Çağatay et al., 2009; Tur et al., 2014; Vardar et al., 2018; Nasıf et al., 2019]. The coarser basal sediments, however, derive from the erosion of tectonic highs, terrestrial inputs, and new hydrodynamic conditions after the LGM. The stratigraphic settings of the seismic sequences at the southern outlet of the Istanbul Strait [e.g. Aksu et al., 1999; Algan et al., 2001; Hiscott et al., 2002; Gökaşan et al., 2005; Eriş et al., 2007; Köprülü et al., 2016] are thicker and more complex, due to variable hydrodynamic conditions and high sediment input, compared to the other parts of the Sea of Marmara [Alavi et al., 1989]. In addition, several recent seismic data sets have also proven complex stratal developments in the lagoons of Büyükçekmece and Küçükcekmece [Vardar et al., 2018; Nasif et al., 2019]. However, the available shallow seismic profiles do not suffice to explain the possible formation and evolution conditions on the northern shelf of the Sea of Marmara. Therefore, there are ongoing discussions about the depositional history of the northern shelf and its relation with the sea/lakelevel fluctuations in the Marmara Basin.

The shelf area between the settlements of Tekirdağ and Şarköy (Figure 1b), the NW margin of the intracontinental marine basin, is mainly controlled by the western continuation of the Northern Strand of the North Anatolian Fault. The portion of the North Anatolian fault between the western Sea of Marmara and the Gulf of Saros is known as the Ganos Fault (GF). The GF system is composed of a series of fault segments disposed to the north and south of a dextral strike slip active master fault observed on land, which connects the western part of the Sea of Marmara to the North Aegean Trough (Figure 1b). The question that could be addressed by our data is how the GF affects the sedimentary strata, and if the deformations along the fault are primary or secondary factors controlling sedimentary evolution. Based on a seismic stratigraphic interpretation carried out on new high-resolution CHIRP profiles recorded at the narrow shelf of the NW Sea of Marmara, this study dwells on the stratigraphic architecture of the study area and the role of the GF on the late Quaternary deposition under variable water depths.

\section{Materials and Methods}

A total of $450 \mathrm{~km}$ of high-resolution single-channel, CHIRP (compressed high-intensity radar pulse) seismic reflection profiles were collected in April 2019 (Figure 1b) between the settlements of Tekirdağ and Şarkoy, along the NW shelf of the Sea of Marmara, using a 13-m long fishing boat. The data were interpreted based on the fundamental principles of sequence stratigraphy [Posamentier et al., 1988]. In order to obtain detailed subbottom survey capability, especially for shallow waters, a Bathy 2010 ${ }^{\text {тм }}$ CHIRP sub-bottom profiler and a bathymetric echo sounder $(2.75-6.75 \mathrm{kHz})$ were used The transmit pulse repetition rate was $1 \mathrm{~Hz}$, depending on the depth range and the selected pulse length; short enough to resolve thin layers covering the sub-bottom strata freeware. The Kogeo Seismic Toolkit was used for basic data processing methods, such as band-pass filtering $(10-15 ; 1750-1900 \mathrm{~Hz})$ and gain adjustment. The boat speed was held constant at 3.5-4.0 knots throughout the CHIRP survey. The approximate depths were calculated using typical velocities of 1500 and $1700 \mathrm{~m} / \mathrm{s}$, for water column and near-surface siliciclastic sediments, respectively [Eriş et al., 2007]. The CHIRP system used in this study is equivalent to a theoretical vertical resolution of $0.125 \mathrm{~m}$; according to the Fresnel zone, the horizontal resolutions are 1.4-2.7 $\mathrm{m}$ for $20 \mathrm{~m}$ water depth. The processed profiles were transferred and interpreted using the Kingdom Suite ${ }^{\circledR}$ (version 8.5; donated by "Seismic MicroTechnology"). The relief maps (unit thickness and surface depth maps) were generated by the "Global Mapper" program and the land elevation data were obtained from ASTER GDEM v2 (NASA/METI/AIST/Japan Spacesystems and U.S./Japan ASTER Science Team, 2009). 


\section{Denizhan Vardar et al.}

\section{Results}

The bathymetric map obtained from the seismic data (Figure $1 \mathrm{~b}$ ) indicates that the shelf is relatively wide between Tekirdağ-Kumbağ ( 10 km) and Gaziköy-Şarkoy, compared to the Kumbağ-Gaziköy sector $(<500 \mathrm{~m})$. The GF is a crustal weakness zone representing the main tectonic element affecting the study area. It is well-defined on land (see Seeber et al., 2004), separating the Eocene clastics/carbonates from the Miocene clastics (Figure 1c).

We identified two main seismic units (U1 and U2) separated by a sequence boundary (the reflector "SB"; see Figures 2a, b; 5a, b, c, d). The SB is characterized as an erosional unconformity at the depths shallow than - $85 \mathrm{~m}$; below this critical depth it is conformable with overlying sediments (Figure $2 \mathrm{a}, 2 \mathrm{~b}$ ). This implies that the erosional part of SB (i.e. above $85 \mathrm{~m} \mathrm{bsl}$ ) underwent subaerial conditions during the LGM lowstand. Moreover, as its paleo-morphology was shaped under the control of the GF, its topography looks rather similar to the recent bathymetry (Figure 3a).

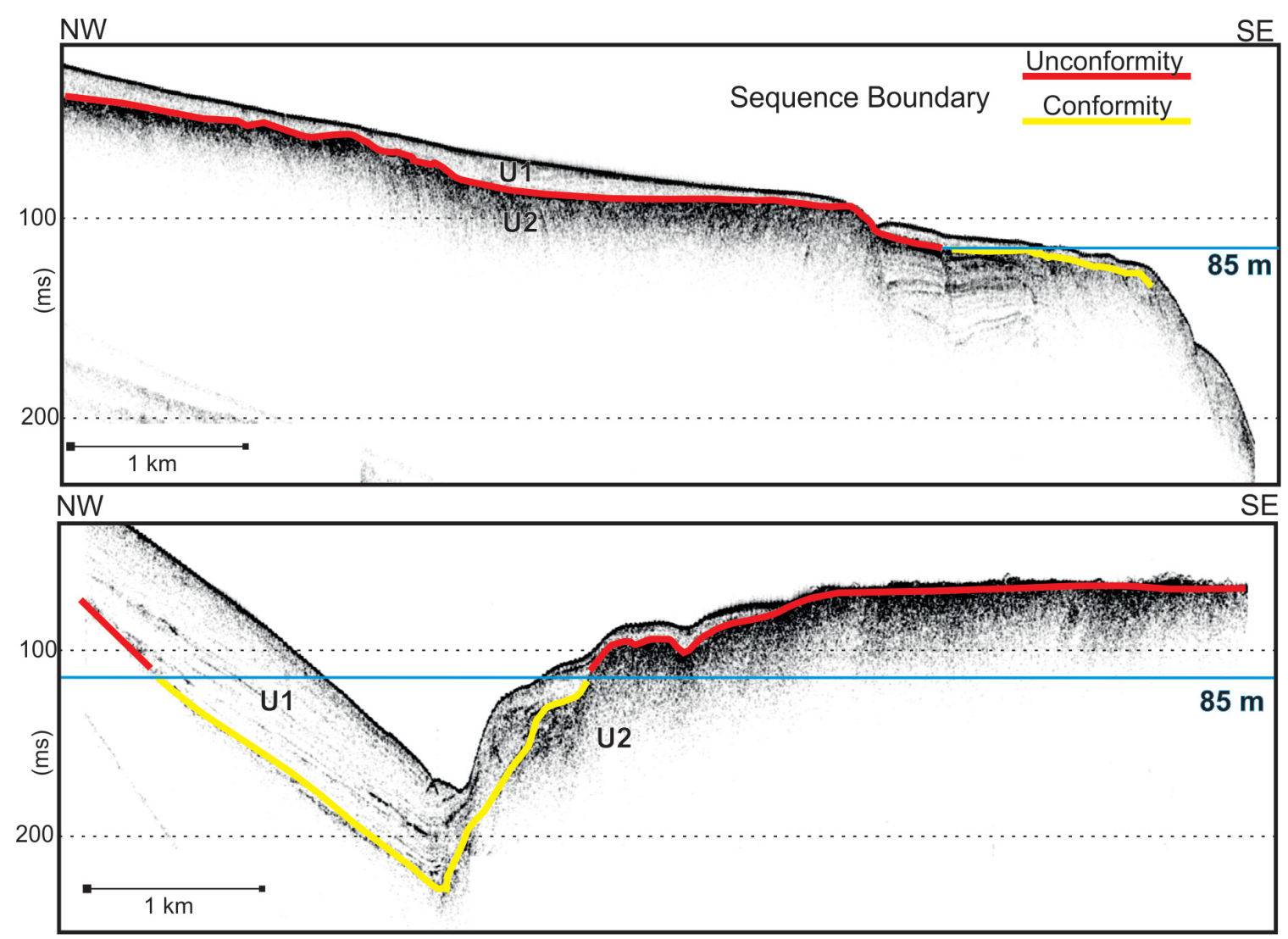

Figure 2. Seismic profiles showing sequence boundary (see Figure 1 for location). $85 \mathrm{~m}$ bsl is the limit between unconformity and conformity.

The upper unit U1 over the SB consists of the sediments deposited since the LGM to the present. As shown by the thickness map (Figure 3b), the unit is rather thin above the wave-cut terraces (Figures 4, 5a) and thickens towards the coast, depending on the increment of terrestrial and fluvial inputs accompanied by local tectonic movements. In fact, unit U1 reaches the greatest thickness at the northern part of the GF (Figures 3a, 5b), while it gets thinner to the south of the GF. The maximum thickness was observed in front of the town of Gaziköy.

According to its internal reflections, truncations, clinoform settings and depositional levels, Unit U1 consists of three parasequences; U1a, U1b and U1c (Figure 4). U1a is characterized by weak, continuous and parallel internal reflections, while U1b consists of roughly parallel to progradational sigmoidal reflections downlapping over SB (Figures $4 ; 5 \mathrm{a}, \mathrm{b}$ ). On the other hand, U1c has a stratified aggradational to progradation progressive internal reflection character (Figures $4 ; 5 \mathrm{c}$ ), and the interface surface with U1a is highly eroded (Figure 5c). 


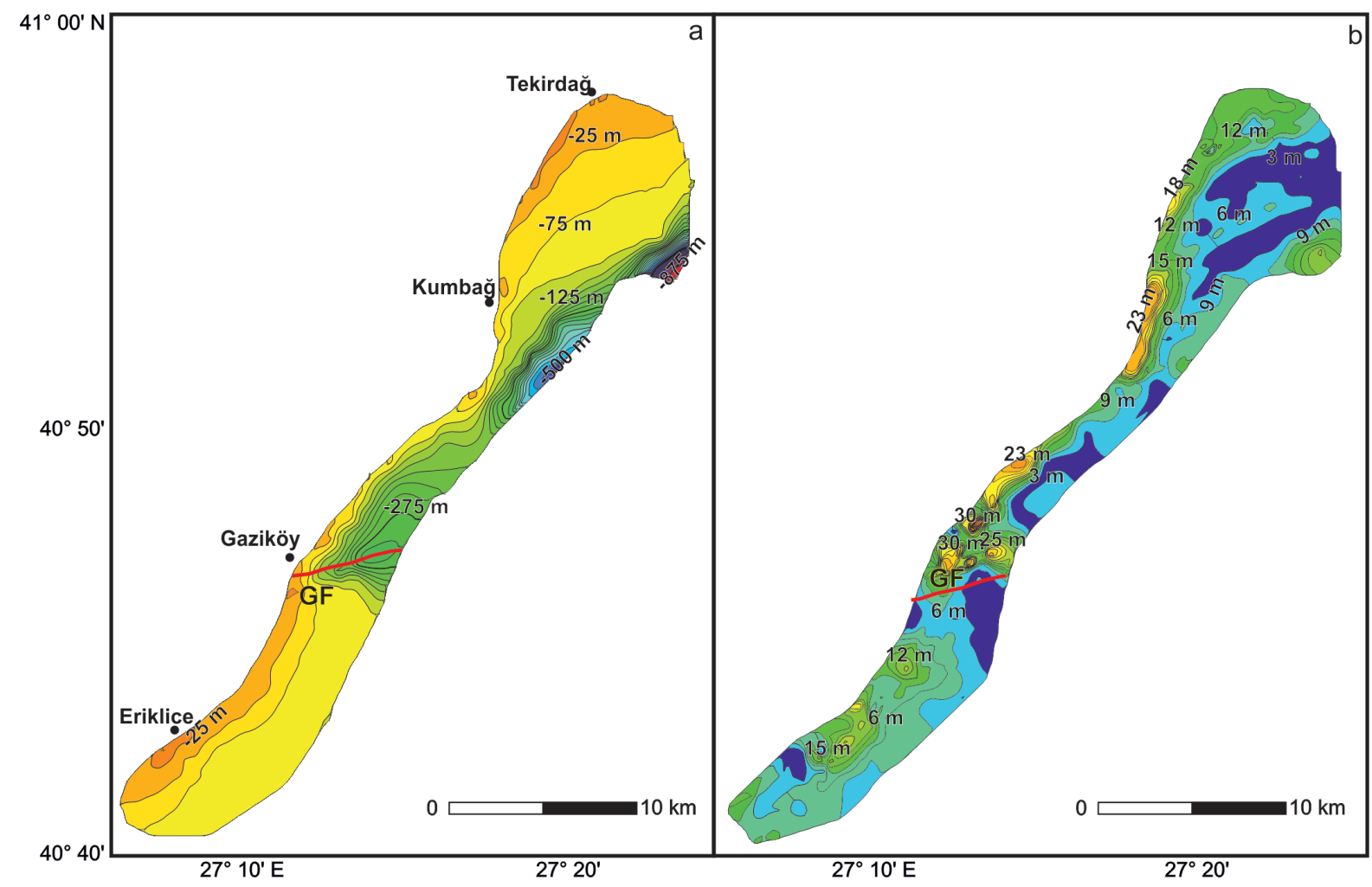

Figure 3. a) Depth contours of SB, b) thickness contours of U1.

The acoustic basement (Unit U2) is characterised by high-angle internal reflections throughout the study area (Figure 4). Wave-cut terraces have been determined at the depths of 49 (65 ms TWT) and 60m (80 ms TWT) bsl (below sea level). The delta front, with its lobate appearance, is at $33 \mathrm{~m}$ (43 ms TWT) bsl.

Sub-unit U1b is only observed offshore from the city of Tekirdağ (Figure 6). Its average thickness is about $15 \mathrm{~m}$ (18 ms TWT) and reaches a maximum thickness of $23 \mathrm{~m}$ (27 ms TWT) near the coast (Figure 6); implying fluvial and terrestrial inputs. The nature of the rollover points of the U1b clinothems show ascending trajectories, implying continued relative sea-level rise, and sea floor accumulation appears to balance it. The ascending pattern marks a balanced terrestrial input associated with its rise to sea level. The average depth of the topset/foreset transitions is $35 \mathrm{~m}$ bsl. Unit U1c, which is dispersed between Gaziköy and Mürefte, thickens to the SW reaching a maximum thickness of $15 \mathrm{~m}$ (18 ms TWT).

\section{Discussion}

The total thickness of unit U1 reaches $30 \mathrm{~ms}$ TWT ( 26 m) near the shore, implying high rates of sediment transportation. These units become thinner towards the shelf break. Unit U1 (Figure 1b) is rather thin above the terraces too, which could be explained by subaerial exposure. It may have been eroded during relative sea-level still stands or transported alongshore by currents, a well-known hydrodynamic factor in the region [Chiggiato et al., 2012]. Unit U1 reaches its maxima ( $40 \mathrm{~ms}$ TWT, $~ 34 \mathrm{~m}$ ) between the towns of Gaziköy and Kumbağ, at the northern side of the GF. The differences in sediment thickness depend on the rate of sediment input, which unknown due to lack of core data, and the variations of the accommodation space under controlled by the tectonic displacement along the GF. 


\begin{tabular}{|c|c|c|}
\hline Unit & Definition & Reflection Pattern \\
\hline U1a & $\begin{array}{l}\text { ow amplitude, paralel to } \\
\text { semi paralel inner } \\
\text { reflections. Concordant with } \\
\text { morphology. }\end{array}$ & 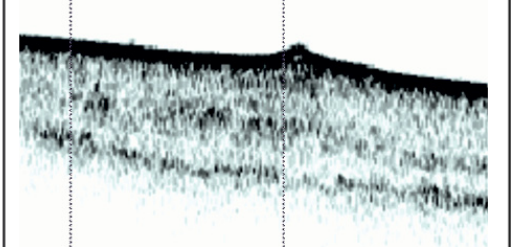 \\
\hline $\mathrm{U} 1 \mathrm{~b}$ & $\begin{array}{l}\text { oughly parallel to } \\
\text { progradational sigmoidal } \\
\text { reflections downlapping on }\end{array}$ & $\bar{x}$ \\
\hline U1c & 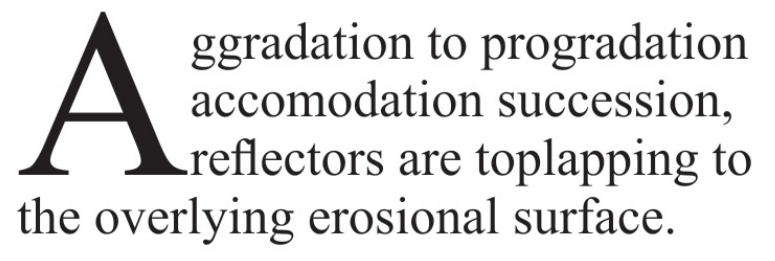 & \\
\hline $\mathrm{U} 2$ & $\begin{array}{l}\text { he acoustic basement, and it } \\
\text { is characterised by high- } \\
\text { angle internal reflections. }\end{array}$ & 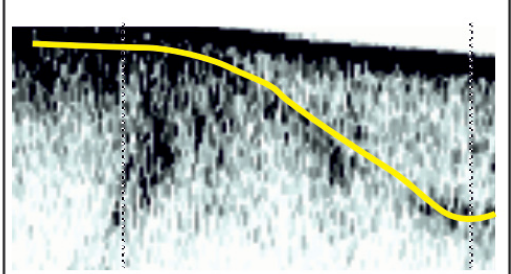 \\
\hline & Wave-Cut Terraces & Rered the \\
\hline & Continental Slope and Gullies & 16 \\
\hline
\end{tabular}

Figure 4. Definitions of the reflection patterns and correlation with the seismic units recorded in the study area. The accommodation successions were interpreted according to Neal and Abreu [2009] and Lobo and Ridente [2014]. 


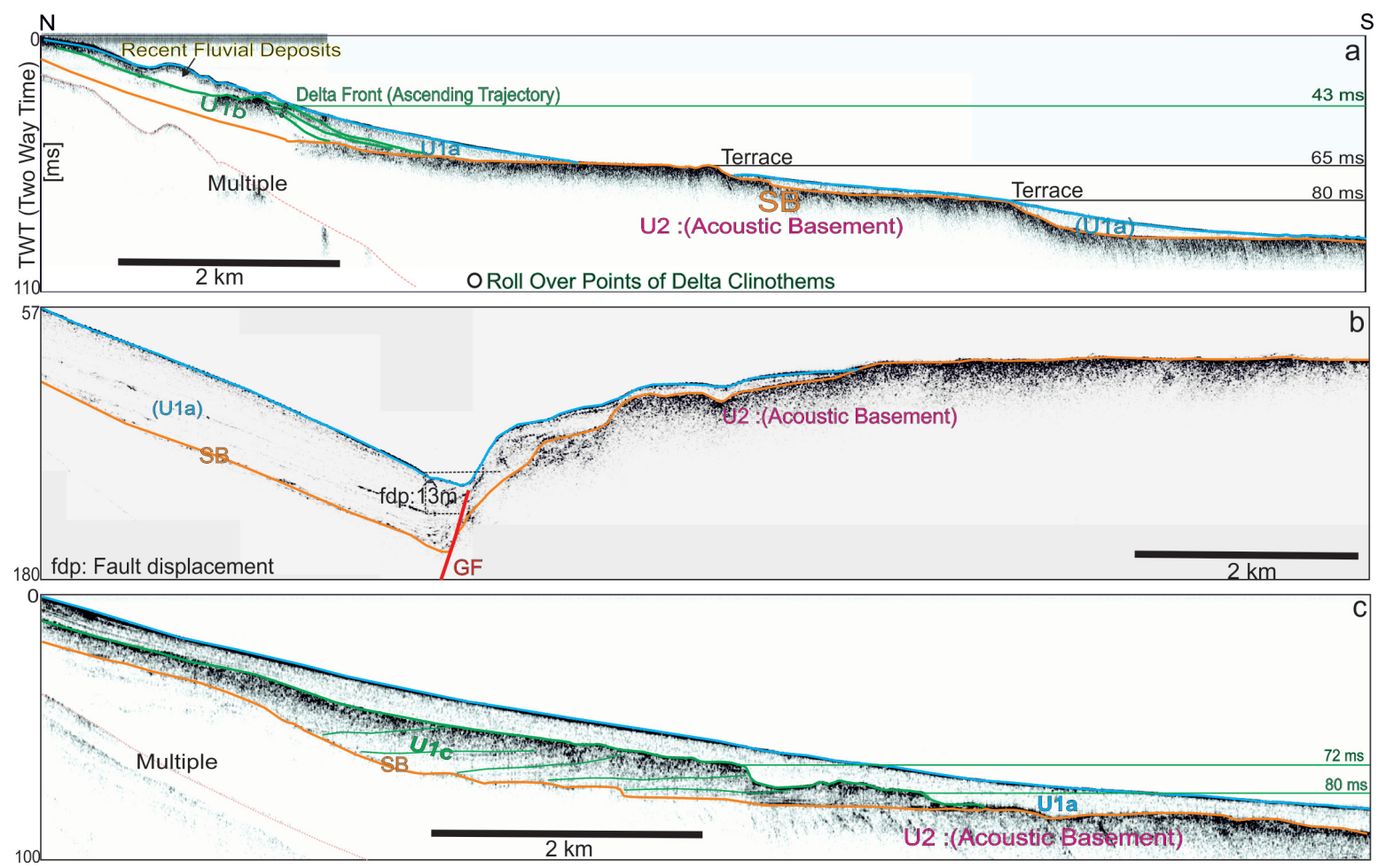

Figure 5. Examples of seismic stratigraphic interpretation in this study (See Figure $1 \mathrm{~b}$ for locations).

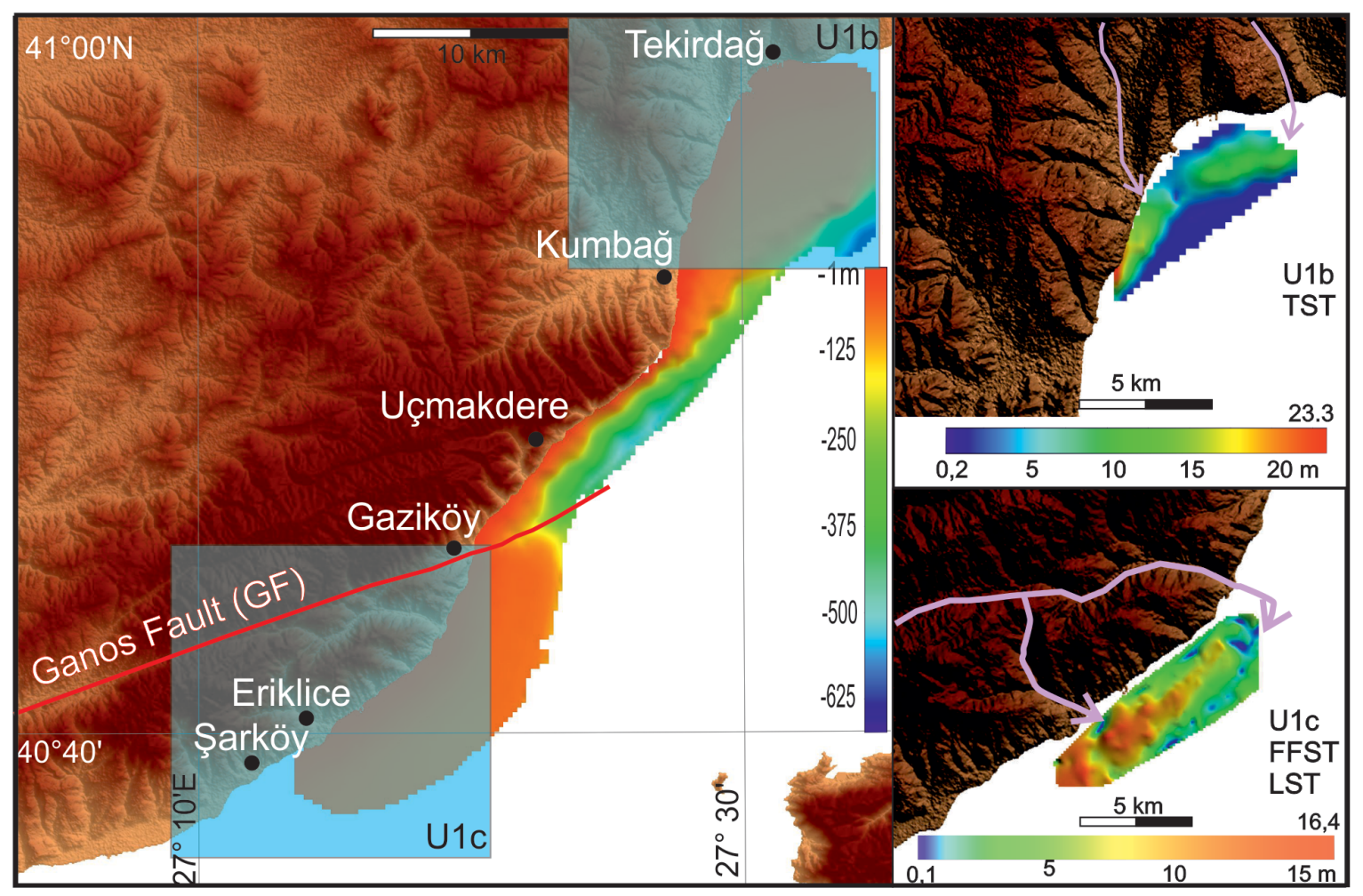

Figure 6. Thickness grids of U1a, U1c and their locations. 


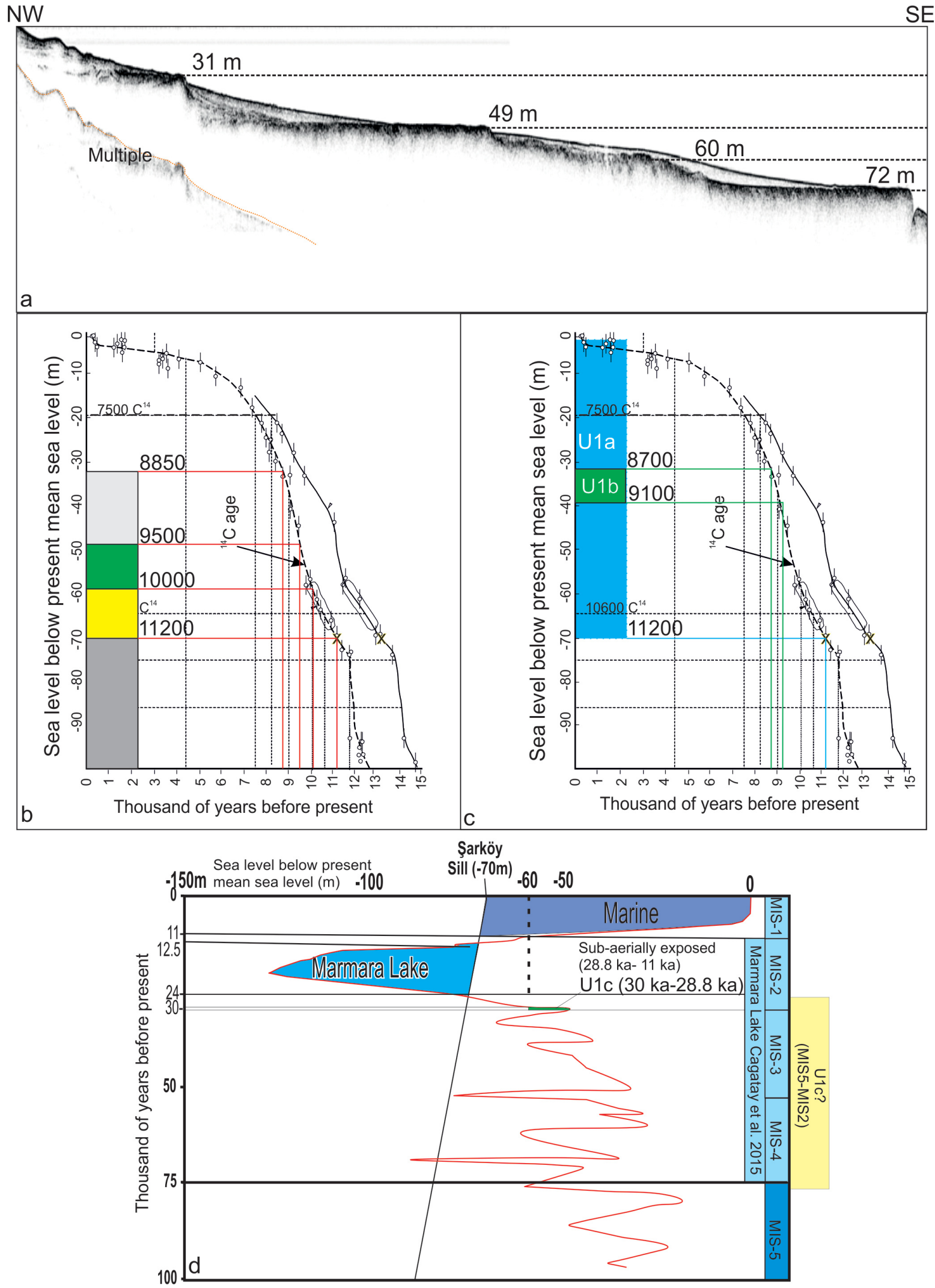

Figure 7. a) Stratigraphic levels associated with possible changes in the water level of the Marmara Sea, Correlation between the global sea curve for the last 15 kyr [Lambeck et al., 2007; Aksu et al., 2016], b) stratigraphic levels, c) parasequences, and d) global sea level constructions representing the last 100 kyr [Williams and Ferrigno, 2012]. The dates given on the $\mathrm{x}$-axis of "b", a and the y-axis of "d" are kyrs before present. 
The thickness of sub-unit U1a, much greater to the north of the GF, should be directly related to cumulative displacements along the fault and its northward-dipping geometry. The stratigraphic setting is characterized by young and relatively thin sediments compared to the accommodation spaces overlying a shelf-crossing acoustic basement, an observation in agreement with other works, e.g. Aksu et al. [1999], Çağatay et al. [2009], Tur et al. [2014], Vardar et al. [2018], Nasif et al. [2019]. On the other hand, our stratigraphic analysis suggests that the presence of two sub-units, U1b and U1c, were controlled by particular sedimentary and tectonic effects occurring between Tekirdağ and Kumbağ, and also between Gaziköy and Şarköy. We note that these two units have a common fluvial origin, as witnessed by their seismostratigraphic characters, including thickness, distribution, accumulation depths, stratification geometries, and that the clinothem patterns and upper surface factors indicate a difference in depositional medium. In this context, the succession geometry of the clinothems of unit U1b is associated with the global sea-level rise; the absence of any erosion on its top also indicates that it is not affected by erosional conditions. Therefore, sub-unit U1b must have been accumulated during a transgressive phase. Conversely, unconformity above sub-unit U1c displays an erosional character, indicating that this unit was deposited during the "falling" and/or "lowstand" phase. Unit U1b can be correlated with such seismo-stratigraphic units identified for the northern shelf of the Sea of Marmara by Hiscott et al. [2002], Çağatay et al. [2003], Gökaşan et al. [2005], Eriş et al. [2007], Köprülü et al. [2016], Vardar et al. [2018] and Nasıf et al. [2019]. However, lowstand deltas such as our Unit U1c are not very common in the Sea of Marmara, those reported by Smith [1995] and Hiscott and Aksu [2002] are an exception. The internal character of Unit U1a also suggests that this sub-unit is of marine origin and was deposited during a transgressive phase. We did not observe stratigraphic unconformity below - $85 \mathrm{~m}$, which is consistent with other studies and suggets the presence of a paleo-shoreline and paleodeltas around the Sea of Marmara [Hiscott et al., 2002; Çağatay et al., 2003; Polonia et al., 2004; Gökaşan et al., 2005; Eriş et al., 2007; Gasperini et al., 2011, 2018; Köprülü et al., 2016, Vardar et al., 2018, Nasıf et al., 2019].

Four levels that can be correlated with the relative still-stand identified at 31, 49, 60, $72 \mathrm{~m}$ bsl. According to the global sea-level curves (Figure 7), these levels can be dated at 8.850, 9.500, 10.000, 11.200 BP respectively. A number of wave-cut terraces were observed at 40,50, 85, 93, and $105 \mathrm{~m}$ bsl along the northern shelf of the Sea of Marmara [Eris et al., 2007, McHugh et al., 2008, Gökaşan et al., 2008, Çağatay et al., 2009]. Moreover, Alp et al. [2018] argued that the shallowest terrace is located at $65 \mathrm{~m}$ bsl while others are at the depths of 87, 94 and 108 $\mathrm{m}$ bsl. Similar marine terraces can be seen in the study area at the $49 \mathrm{~m}$ and $60 \mathrm{~m}$ bsl. The differences in depth between the terraces compared to the other levels in the northern shelf of the Sea of Marmara can be explained by the relative amount of uplift [e.g. Bulkan et al., 2020, Vardar et al., 2021] under the influence of the GF. The sigmoidal-shaped inner reflections of Unit U1b between Tekirdağ and Kumbağ is progradational, the ascending trajectories of rollover points can be correlated with sea level rise during clinothem development, and delta front is at $43 \mathrm{~ms}$ (TWT) bsl. Therefore, unit U1b could probably be classified as a Transgressive System Tract (TST), like U1a. Unit U1a seems to have been evolving since 11,200 BP according to correlations with the sea-level curve (Figure 7), while the evolution period of Unit U1b must be between 9,100 and 8,700 BP. Unit U1b can be associated with unit D2 of Vardar et al. [2018]. The eroded top surface of unit U1c implies that the unit was exposed subaerially during the LGM, i.e. the unit was deposited during the falling stage (FFST) and lowstand system tracts (LST). The deposition of unit U1c must have started with the transition of marine conditions to lacustrine conditions, under the influence of a global decrease in sea level; possibly between 30 and $28.8 \mathrm{kyr}$ BP (Figure 7c). According to Çağatay et al. [2015], the study area was under lacustrine conditions between MIS 4-MIS 1. Since the hiatus observed between units U2 and U1c is not certain, this result should be confirmed. Our study area partly overlaps with the sediment coring sites (C1-C13) of Ergin et al. [2007] who outlined the sedimentary units (i.e. U1 to U4, from bottom to top) over the pre-Miocene basement and dated selected sediment samples from the basement of three cores as $14 \mathrm{C}$ years $\mathrm{BP}$ and corrected for $13 \mathrm{C}$. These units are above the pre-Miocene basement and cover a time span from Late Miocene (their unit U1) to the last glacial period and early phase of the interglacial period. Unit U4 in their study can extend to our study area and corresponds to all of the overlying units above our acoustic basement. Unit U2, described as the acoustic basement in this study, can be correlated with the onshore geology (Figure 1b). Using our findings and taking into account the dextral strike-slip displacement of the GF, unit $\mathrm{U} 2$ can be correlated with the Eocene clastics and carbonates fm. at the northern part of the GF, and to the Miocene clastics fm. to the south.

Correlations with available core samples and seismic profiles in this study are given in Figure 8. According to the lithological definition of cores " 1,2 , and 3", unit U1b is related with shelly, gravelly and sandy units that 
Denizhan Vardar et al.
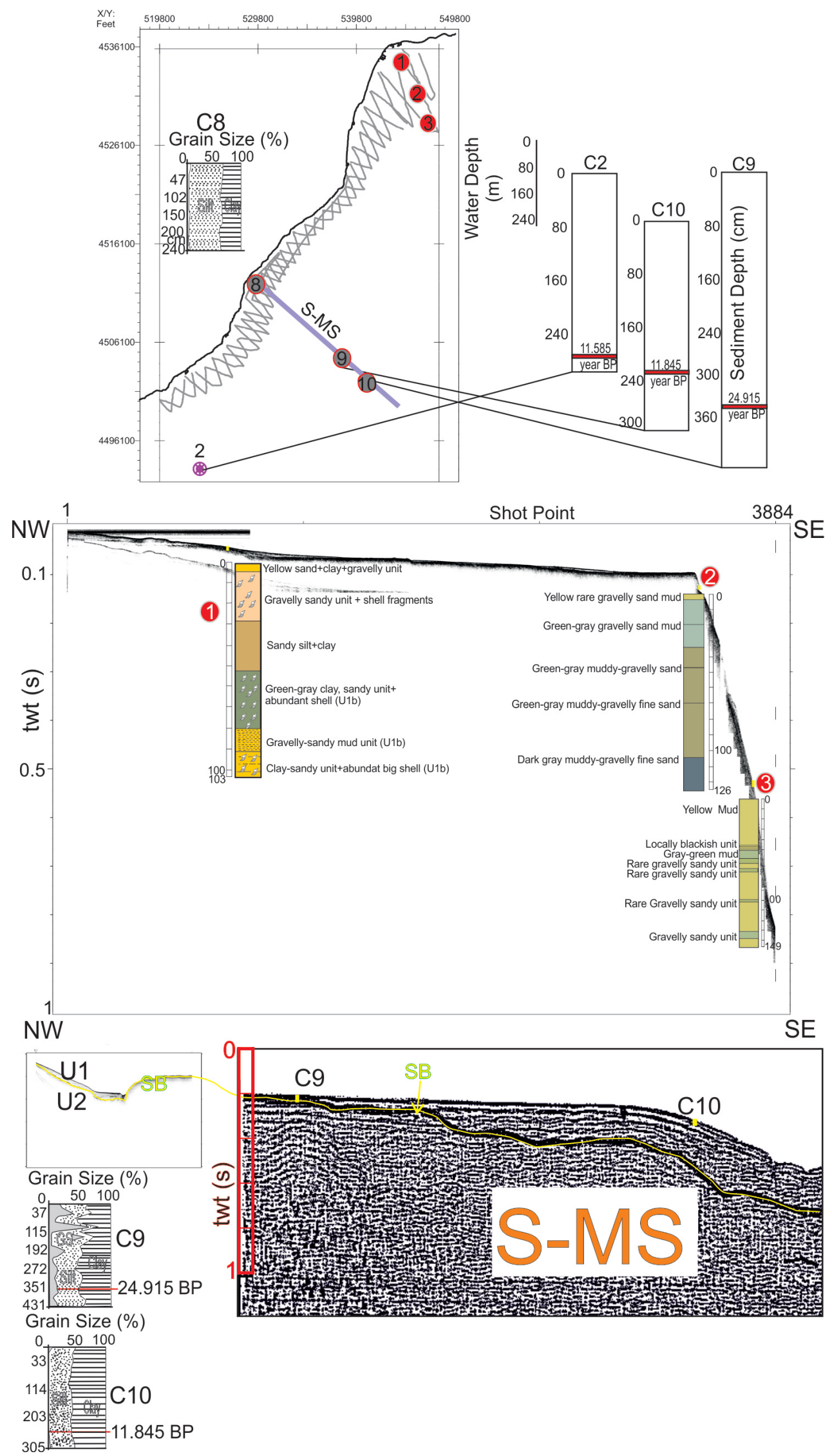

Figure 8. Lithology, ages and locations of available cores for study area. Correlations between cores and new seismic profiles, and superimposed figure of the seismic data of Ergin et al. [2007] with CHIRP data. 
confirm fluvial and terrestrial siliciclastic sources. The texture of the sea bottom sediments gets thinner, from coarse-grained sediments on the coast to fine-grained ones at the shelf-break. The general lithological characteristic of the cores given by Ergin et al. [2007] indicate higher-energy conditions over the eroded substrate of near shore, while lower-energy conditions predominate on the slope.

Although our seismic profiles cannot be associated directly with cores 9-10 of Ergin et al. [2007], the CHIRP data (Figure 8) is well-matched with their multichannel seismic profile. Depending on this similarity and using the core dates given by Ergin et al. [2007], the bottom of unit U1a can be dated between 11.200 and $11.585 \mathrm{BP}$. Similarly, using the dates calculated for Core 9, the SB can be dated 24.815 BP (Figure8). There are time and sealevel differences in the effects of global sea-level changes on the deposition and erosional stages in the Sea of Marmara. During the LGM period, the sea level in the North Aegean Sea was about $120 \mathrm{~m}$ bsl [Simaiakis et al., 2017] whilst it was about $100 \mathrm{~m}$ bsl on the Romanian Black Sea coast [Lericolieas et al., 2007]. Yanchlina et al. [2017] have shown an ancient shoreline varying between $80-100 \mathrm{~m}$ bsl for the entire Black Sea. In the Sea of Marmara, the sea level associated with the last glacial period is around $85 \mathrm{~m} \mathrm{bsl}$; meaning that the Sea of Marmara has a unique depositional and erosional system that differs from its neighbouring seas. In this context, the sea levels obtained in this study and dating corrections made by the previous studies are rather important for defining this marine basin, as well as other similar inland seas, which have their own distinctive marine characteristics.

\section{Conclusions}

Distribution and associated seismic facies of seismic units along the NW shelf of the Sea of Marmara, above an erosional surface (Sequence Boundary, SB) indicate inputs of fluvial, terrestrial and marine origin, starting from the LGM. A stratigraphic analysis of the high-resolution reflection profiles led to recognition of two main seismic units (U1 and U2) and three para-sequences (U1a, U1b and U1c), mainly controlled by water-level changes and regional tectonics. In fact, the thickness of the units, as well as their distribution along the shelf, has been controlled by seismic activities along the Ganos Fault. The erosional truncations observed along the slopes and deepening of the $\mathrm{E}-\mathrm{W}$ trending basin were controlled by the dominant tectonic regime in the region. Moreover, the tectonic deformations also affect the external shapes of the sedimentary units and their internal reflections. The marine terraces observed in the study area are located at shallower depths compared to those along the northern shelf, possibly due to regional tectonic uplift.

Another finding regards the discrepancies observed between the global sea-level curves and the water-level changes in this semi-closed inland sea, indicating that water-level changes in the Sea of Marmara are unique and not fully dependent on the eustatic oscillations of the oceans and the adjacent seas. Although we have provided some dating data representing the key reflectors, deeper cores and dating at frequent intervals are needed to reveal more detailed sea level changes.

\section{References}

Aksu, A. E., R. N. Hiscott and D. Yaşar (1999). Oscillating Quaternary water levels of the Marmara Sea and vigorous outflow into the Aegean Sea from the Marmara Sea-Black Sea drainage corridor, Mar. Geol., 153, 275-302.

Aksu, A. E., R. N. Hiscott and C. Yaltırak (2016). Early Holocene age and provenance of a mid-shelf delta lobe south of the Strait of Bosphorus, Turkey, and its link to vigorous Black Sea outflow, Mar. Geol., 380, 113137.

Alp, H., D. Vardar, B. Alpar and T. Ustaömer (2018). Seismic evidence for change of the tectonic regime in Messinian, northern Marmara Sea, Turkey, JAES 151, 40-53.

Alavi, S. N., M. Okyar and K. Timur (1989). Late Quaternary sedimentation in the Strait of Bosphorus: High resolution seismic profiling, Mar. Geol., 89,185-205.

Algan, O., N. Çağatay, A. Chepalyga, D. Ongan, C. Eastoe and E. Gökaşan (2001). Stratigraphy of the sediment infill in the Bosphorus Strait: Water exchange between the Black and Mediterranean Seas during the Last 


\section{Denizhan Vardar et al.}

Glacial-Holocene, Geo-Mar. Lett., 20, 209-218.

Bulkan, S., P. Henry, P. Vannucchi, F. Storti, C. Cavozzi and J. P. Morgan (2020). The evolution of restraining and releasing bend pairs: analogue 2 modelling investigation and application to the Sea of Marmara, doi.org/10.1002/essoar.10502140.1

Çağatay, M. N., N. Görür, O. Algan, C. J. Eastoe, A. Tchapalyga, D. Ongan, T. Kuhn and I. Kuşçu (2000). Late Glacial-Holocene paleoceanography of the Sea of Marmara: Timing of connections with the Mediterranean and the Black Seas, Mar. Geol., 167, 191-206.

Çağatay, M. N., N. Görür, A. Polonia, E. Demirbağ, M. Sakınç, M. H. Cormier, L. Capotondi, C. McHugh, O. Emre and K. Eris (2003). Sea-level changes and depositional environments in the Izmit Gulf, eastern Marmara Sea, during the Late Glacial-Holocene period, Mar. Geol., 202, 159-173.

Çă̆atay, M. N., K. Eriş, W. B. F. Ryan, U. Sancar, A. Polonia, S. Akcer, D. Biltekin, L. Gasperini, N. Görür, G. Lericolais and E. Bard (2009). Late Pleistocene-Holocene evolution of the northern shelf of the Sea of Marmara, Mar. Geol., 265, 87-100.

Çağatay, M. N., S. Wulf, U. Sancar, A. Ozmaral, L. Vidal, P. Henry, O. Appelt and L. Gasperini (2015). The tephra record from the Sea of Marmara for the last ca. $70 \mathrm{ka}$ and its palaeoceanographic implications, Mar. Geol., 361, 96-110.

Chiggiato, J., E. Jarosz, J. W. Book, J. Dykes, L. Torrisi, P. M. Poulain, R. Gerin, J. Horstmann and Ş. Beşiktepe (2012). Dynamics of the circulation in the Sea of Marmara: numerical modeling experiments and observations from the Turkish straits system experiment, Ocean Dynamics, 62, 139-159, https://doi.org/10.1007/s10236-011-0485-5ç

Eris, K. K., W. B. F. Ryan, M. N. Çağatay, U. Sancar, G. Lericolais, G. Menot and E. Bard (2007). The timing and evolution of the post-glacial transgression across the Sea of Marmara shelf south of Istanbul, Mar. Geol., 243, 57-76.

Ergin, M., E. Uluadam, K. Sarikavak, Ş. Keskin, E. Gökaşan and H. Tur (2007). Late Quaternary sedimentation and tectonics in the submarine Şarköy Canyon, western Marmara Sea (Turkey), Geological Society, London, Special Publications 291(1), 231-257.

Gasperini, L., A. Polonia, M. N. Çağatay, G. Bortoluzzi and V. Ferrante (2011). Geological slip rates along the North Anatolian Fault in the Marmara region, Tectonics, 30, TC6001, http://dx.doi.org/10.1029/2011TC002906

Gasperini, L., A. Polonia and M. N. Çağatay (2018). Fluid flow, deformation rates and the submarine record of major earthquakes in the Sea of Marmara, along the North-Anatolian Fault system, Deep Sea Res. Part II: Topical Studies in Oceanography, 153, 4-16.

Gökaşan, E., O. Algan, H. Tur, E. Meric, A. Turker and M. Şimşek (2005). Delta formation at the southern entrance of Istanbul Strait (Marmara Sea, Turkey): A new interpretation based on high-resolution seismic stratigraphy, Geo-Mar. Lett., 25, 370-377.

Gökaşan, E., M. Ergin, M. Özyalvaç, H. İ. Sur, H. Tur, T. Görüm, T. Ustaömer, F. G. Batuk, H. Alp, H. Birkan, A. Türker, E. Gezgin and M. Özturan (2008). Factors controlling the morphological evolution of the Çanakkale Strait (Dardanelles, Turkey), Geo-Mar. Lett., 28, 107-129.

Hiscott, R. N. and A. E. Aksu (2002). Late Quaternary history of the Marmara Sea and Black Sea from highresolution seismic and gravity-core studies, Mar. Geol., 190: 261-282.

Hiscott, R.N., A. E. Aksu, D. Yasar, M. A. Kaminski, P. J. Mudie, V. E. Kostylev, J. C. MacDonald, F. I. Isler and A. R. Lord (2002). Deltas south of the Bosphorus Strait record persistent Black Sea outflow to the Marmara Sea since 10 ka, Mar. Geol., 190, 95-118.

Köprülü, K., B. Alpar and D. Vardar (2016). Last Glacial - Holocene stratigraphic development at the Marmara Sea exit of the Bosphorus Strait, Turkey, Mar. Geophys. Res., 37, 1, 21-35.

Lambeck, K., D. Siva and A. Purcell (2007). Timing of the last Mediterranean Sea-Black Sea connection from isostatic models and regional sea-level data. In: The Black Sea Flood Question: Changes in Coastline, Climate and Human Settlement (eds) Yanko-Hombach V, Gilbert A S, Panin N and Dolukhanov P M, Springer, The Netherlands, 797-808.

Lericolieas, G., I. Popescu, F. Guichard, S. M. Popescu and L. Manolakakis (2007). Water-level fluctuations in the Black Sea since the Last Glacial Maximum, in Yanko-Hombach, V., Gilbert, A.S., Panin, N., and Dolukhanov, P.M., eds., The Black Sea Flood Question: Changes in Coastline, Climate, and Human Settlement: 
Berlin, Springer, p. 437-452.

Lobo, F.J. and D. Ridente (2014). Stratigraphic architecture and spatio-temporal variability of high-frequency (Milankovitch) depositional cycles on modern continental margins: An overview, Mar. Geol., 352, 215247

McHugh, C. M. G., D. Gurunga, L. Giosanc, W. B. F. Ryan, Y. Mart, U. Sancar, L. Burckle and M. N. Çağatay (2008). The last reconnection of the Marmara Sea (Turkey) to the World Ocean: A paleoceanographic and paleoclimatic perspective, Mar. Geol., 255, 64-82.

Nasif, A., D. Dondurur and D. Vardar (2019). Stratigraphical and morphological aspects of the northern Marmara shelf based on seismic data, J. Earth Syst. Sci., 128, 54.

Neal, J. and V. Abreu (2009). Sequence stratigraphy hierarchy and the accommodation succession method, Geology, 37, 9, 779-782; doi:10.1130/G25722A.

Polonia, A., L. Gasperini, A. Amorosi, E. Bonatti, N. Çağatay, L. Capotondi, M. H. Cormier, N. Gorur, C. McHugh, and L. Seeber (2004). Holocene slip rate of the North Anatolian Fault beneath the Sea of Marmara, Earth Planet. Sci. Lett., 227, 411 - 426, doi:10.1016/j.epsl.2004.07.042.

Posamentier, H. W. and P. R. Vail (1988). Eustatic controls on clastic deposition II - Sequence and systems tract models; In: Sea-level Changes: An Integrated Approach, Posamentier H W, Ross C A and Van Wagoner J C (eds), Soc. Econ. Paleontol. Mineral Spec. Publ., 42, 125-154.

Posamentier, H. W., G. P. Allen, D. P. James and M. Tesson (1992). Forced regressions in a sequence stratigraphic framework: Concepts, examples, and exploration significance, Am. Assoc. Petrol. Geol. Bull., 76, 16871709.

Seeber, L., O. Emre, M. H. Cormier, C. C. Sorlien, C. M. G. McHugh, A. Polonia, N. Özer and N. Çağatay (2004). Uplift and subsidence from oblique slip: the Ganos-Marmara bend of the North Anatolian Transform, Western Turkey, Tectonophysics 391, 239-258.

Simaiakis, S. M., K. F. Rijsdijk, E. F. M. Koene, S. J. Norder, J. H. Van Boxel, P. Stocchi, C. Hammoud, K. Kougioumoutzi, E. Georgopolou, E. Van Loon, K. M. C. Tjorve and E. Tjorve (2017). Geographic changes in the Aegean Sea since the Last Glacial Maximum: Postulating biogeographic effects of sea-level rise on islands, Palaeogeography, Palaeoclimatology, Palaeoecology, 471, 108-119.

Smith, A. D., T. Taymaz, F. Oktay, H. Yüce, B. Alpar, H. Başaran, J. A. Jackson, S. Kara and M. Şimşek (1995). High resolution seismic profiling in the Sea of Marmara (northwest Turkey): Late quaternary sedimentation and sea-level changes, GSA Bull., 107, 923-936.

NASA/METI/AIST/Japan Spacesystems and U.S./Japan ASTER Science Team (2009). ASTER Global Digital Elevation Model [Data set]. NASA EOSDIS Land Processes DAAC. Accessed 2020-02-04 from https://doi.org/10.5067/ASTER/ASTGTM.002

Tur, H., N. Hoşkan and G. Aktaş (2014). Tectonic evolution of the northern shelf of the Marmara Sea (Turkey): Interpretation of seismic and bathymetric data, Mar. Geophys. Res., 36, 1-34.

Vail, P. R. (1987). Seismic stratigraphy interpretation using sequence stratigraphy. Part 1: Seismic stratigraphy interpretation procedure; AAPG Studies in Geology 27 1-10.

Van Wagoner, J. C., H.W. Posamentier, R. M. Mitchum, P. R. Vail, J. F. Sarg, T. S. Louit and J. Hardenbol (1988). An overview of the fundamentals of sequence stratigraphy and key definitions; In: Sea-Level Changes: An Integrated Approach (eds) Wilgus C K, Hastings B S, Kendall C G St C, Posamentier H W, Ross C A, Van Wagoner J C, SEPM Spec. Publ., 42, 39-45.

Vardar, D., K. Öztürk, C. Yaltırak, B. Alpar and H. Tur (2014). Late Pleistocene-Holocene evolution of the southern Marmara shelf and sub-basins: middle strand of the North Anatolian fault, southern Marmara Sea, Turkey, Mar. Geophys. Res., 35, 69-85.

Vardar, D. and H. Aykurt Vardar (2014). Plio-Quaternary sandy deposits and microbial buildups at the southern Marmara shelf near shoreface area, Turkey, Int. J. Environ. Geoinform., 1, 40-47.

Vardar, D., H. Alp and B. Alpar (2018). Seismic stratigraphy and depositional history of the Büyükçekmece Bay since Latest Pleistocene, Marmara Sea, Turkey, J. Earth Syst. Sci., 127, 13.

Vardar, D., H. Alp, S. Demirel, H. Aykurt Vardar and B. Alpar (2021). Offshore/onshore correlation of the NorthAnatolian fault deformations in the Western Sea of Marmara, Nat. Hazards, https://doi.org/10.1007/s11069-021-04664-2

Vidal, L., G. Menot, C. Joly, H. Bruneto, F. Rostek, M. N. Çağatay, C. Major and E. Bard (2010). Hydrology in the 


\section{Denizhan Vardar et al.}

Sea of Marmara during the last $23 \mathrm{ka}$ : Implications for timing of Black Sea connections and sapropel deposition, Paleoceanography, 25.

Williams, R. S. Jr and J. G. Ferrigno (2012). State of the Earth's cryosphere at the beginning of the 21st centuryglaciers, global snow cover, floating ice, and permafrost and periglacial environments, U.S. geological survey professional paper 1386-A, 546 p. http://pubs. usgs.gov/pp/p1386a

Yanchlina, A. G., W. B. F. Ryan, J. F. McManus, P. Dimitrov, D. Dimitrov, K. Slavova and M. Filipova-Marinova (2017). Compilation of geophysical, geochronological, and geochemical evidence indicates a rapid Mediterranean-derived submergence of the Black Sea's shelf and subsequent substantial salinification in the early Holocene, Mar. Geol., 383, 14-34. 